\title{
Characteristics of Speech Intelligibility and Speech Acceptability Connected with Interdentalized /s, $\mathrm{s}^{*} /$
}

\author{
Yun-Kyung Song \\ Department of Communication Disorders, College of Health, Welfare and Education, Tongmyong University, Busan, Korea
}

\section{/ㅅ, $\mu$ / 음소의 치간음화에 따른 말 명료도 및 말 용인도 특성}

송 윤 경

동명대학교 보건복지교육대학 언어치료학과

\begin{abstract}
Purpose: The purpose of this study was to compare the scores of speech intelligibility and speech acceptability in normal and interdentalized Korean fricative $/ s, s^{*} /$ in word and sentence level. Methods: 36 words with $/ s, s^{*} /$ sounds and 10 sentences with $/ s, s^{*} /$ sounds words were recorded by two women with R-05 Wave/MP3 Recorder (Roland). After listening the normal and interdentalized /s, s*/ words and sentences, 54 female undergraduate students scored the speech intelligibility and speech acceptability. Results: The scores of speech intelligibility and speech acceptability in interdentalized $/ \mathrm{s}, \mathrm{s} /$ words and sentences were significantly lower than the scores of those in normal Korean $/ \mathrm{s}, \mathrm{s} * /$ words and sentences. And the scores of speech acceptability were significantly lower than those of speech intelligibility in interdentalized $/ s, s^{*} /$ words and sentences. Conclusion: These results showed that the general female undergraduate students were impressed the words and sentences with interdentalized $/ s, s^{*} /$ were less intelligible and less acceptable rather than normal $/ s, s^{*} /$ words and sentences. These results can be applied to diagnosis and treatment of subjects with interdentalized fricative $/ \mathrm{s}, \mathrm{s}^{*} /$ in Korean.
\end{abstract}

Key Words: Interdentalized Korean fricative, Speech intelligibility, Speech acceptability.

Received: September 21, 2018 / Revised: October 12, 2018 / Accepted: October 15, 2018

Correspondence: Yun-Kyung Song, Department of Communication Disorders, College of Health, Welfare and Education, Tongmyong University, 428 Sinseon-ro, Nam-gu, Busan 48520, Korea

Tel: +82-51-629-2128 / Fax: +82-51-629-2019 / E-mail: voicesyk@hanmail.net

\section{INTRODUCTION}

한국어의 치경마찰음 /ㅅ, 씨 음소는 정상 아동의 말소리 발 달 과정에서 가장 늦게 습득되는 말소리에 속하며, 긴 시간 동안 점진적인 과정을 통하여 발달되는 소리이다. 또한 조음 오류를 보이는 아동에게서 가장 자주 오조음되는 말소리로 알려져 있 기도 하다. Cheon \& Lee(1999)에 의하면 한국어 치경마찰음 /ㅅ, 씨는 생략 및 /ㅎ/로부터 시작하여 치경파열음 /ᄃ, ㄸ, $E /$, 파찰음 /ᄌ, ㅉ, ㅊ/, 구개음화된 마찰음 $/ 6,6 \% /$, 그리고 치간음화 된 마찰음 $/ \theta, \theta^{*} /$ 의 과정을 거쳐 발달하는 것으로 나타났다. 영

(c) This is an Open Access article distributed under the terms of the Creative Commons Attribution Non-Commercial License (https://creativecommons.org/licenses/by-nc/4.0) which permits unrestricted non-commercial use, distribution, and reproduction in any medium, provided the original work is properly cited.
어권에서도 /s, z/ 음소는 학교 언어치료실에서 가장 빈번한 치 료 목표가 되고 있으며, 이 소리들을 치간음화시키는 오류가 말 소리 산출 오류 중에서 가장 흔한 것으로 보고되었다(Shriberg \& Kent, 2013).

치경마찰음 /시스는 혀를 치경에 완전히 접촉시키지 않고 일정 간격을 지속적으로 유지하며 산출하기 때문에 섬세한 조 음 능력이 요구되는 소리이다(Heo \& Seong, 2015). 또한 / 시 씨 는 다른 소리에 비하여 습득 기간이 길고 조음의 정교성이 요 구되는 소리이기 때문에 아동뿐 아니라 성인에서도 비교적 흔 한 말소리 오류로 나타나고 있다. 이 말소리들의 오류는 생략이 나 대치의 경우라면 청지각적인 평가에서 확연한 차이를 나타 내기 때문에 비교적 판단이 용이한 편이다. 그러나 왜곡된 / 스, 씨 소리는 청지각적으로 정확한 판단이 어려울 때가 있으며, 
특히나 주관적 판단이라는 제한점을 가지고 있기 때문에 진단 뿐 아니라 치료의 진전을 평가할 때도 그 한계점이 있는 것이 지적되었다(Pyo et al., 1999).

이와 같은 이유로 연구자들은 치경마찰음 / 스, 씨를 음향학적 평가를 통하여 그 소리의 특성을 파악하고, 특히 왜곡된 소리의 특성을 객관적으로 평가할 수 있는 방법을 연구해왔다. Heo \& Seong(2015)은 만 7세 아동의 완성된 치경마찰음 / 시와 관습적 연령 단계인 만 3세 아동의 발달 과정에 있는 / 시를 비교 분석 하여 발달상 나타나는 음향학적 차이를 제시하였다. 연구 결과 /시 음소의 왜도, 무게중심, 첨도, 중앙적률 값은 연령 집단 간, 모음 환경 간, 음절 구조 사이에서 유의미한 차이를 나타내었으 나, 그 구체적인 실현 양상은 매우 다양함을 알 수 있었다. 동시 에 3세 집단은 /수, 스/와 /소, 서/를 하나의 집단으로 간주하는 경향이 있으므로 3 세 아동을 대상으로 하는 조음 치료 시에 이 짝을 구분하는 훈련에서부터 시작하면 좋을 것이라는 점을 제 안하였다. 또한 Yang(2016)은 / 시 씨 음소에서 구개음화, 치간 음화 또는 설측음화의 왜곡 오류를 보이는 초등학생 조음음운 장애 아동과 일반 아동의 치경마찰음 /ㅅ, 씨 소리를 결합된 모 음 종류에 따라 음향학적으로 비교, 분석하였다. 그 결과 기능 적 조음음운장애 아동의 치경마찰음 관련 음향학적 측정 값들 은 일반 아동에 비하여 평균 범위에서 넓게 퍼져 다양하게 분포 하는 것을 알 수 있었다. $\operatorname{Kang}(2016)$ 역시 /ㅅ, 씨 음소를 치간 음화, 구개음화, 설측음화로 왜곡시키는 4 6세 아동 10명의 발 화 자료를 음향학적으로 분석하여 언어치료사들이 평정한 청 지각적 평가 자료와 비교해 그 관련성을 살펴보았다. 그 결과 /ㅅ, 씨의 무게중심 값이 증가할수록 청지각적 평정 수치는 높아 지고, 고모음을 제외한 경우 왜도 값이 증가할수록 청지각적 평 정 수치는 낮아지며, 분산 값이 증가할수록 청지각적 평정 수치 가 높아질 것을 예측할 수 있었다. /스, 씨 음소를 음향학적으로 분석한 이 연구들은 스펙트럼 분석을 통하여 왜도(skewness), 무게중심(center of gravity), 첨도(kurtosis), 중앙적률(center moment) 등의 파라미터를 공통적으로 사용하였으며, 그 결과 로 연령 집단의 차이나 정상 발음과 왜곡된 발음의 차이를 객 관적으로 비교하여 평가할 수 있는 점들을 정리하였고, 또한 치 료에서 적용할 수 있는 유의점들을 제시하였다. 이와 같은 선행 연구들은 치경마찰음 / 스, 씨가 정조음되거나 또는 왜곡되는 상황에서 청지각적 평가가 가지는 한계점을 극복하고 보다 객 관화된 방법으로 평가하거나 치료에 도움을 주기 위한 구체적 인 방법을 찾기 위한 시도라고 판단된다.

그럼에도 불구하고 임상에서 가장 일반적인 말소리 평가는 자음정확도(percentage of correct consonant)나 모음정확도 (percentage of correct vowel)와 같은 조음정확도로 해당 음 소를 정확하게 산출하였는지 듣고 평가하는 것이다. 이는 대부
분의 말소리장애 평가에서 가장 기본적으로 적용하는 평가 방 법이기도 하다. 그 외에 말 명료도(speech intelligibility)나 말 용인도(speech acceptability)는 조음정확도만으로 평가하거나 비교하기 어려운 경우 또는 다양한 말소리장애 영역에서 그 특 성이나 중증도 및 치료 효과를 평가하기 위한 수단으로 사용되 어 왔다. 말 명료도는 발화자가 전달하려는 내용이 청자에게 얼마나 잘 전달되었는가의 정도, 즉 청자가 얼마나 잘 알아들었 는가의 정도를 의미하며, 말 용인도는 전달되는 말에서 느껴지 는 자연스러움(naturalness)이나 호감(pleasantness)의 정도에 대한 청자의 판단을 의미한다(Ellis, 1999). 이와 같은 파라미터 는 마비말장애 환자나 후두적출자의 식도 발성이나 인공후두 발성의 말소리 평가, 구개열 아동의 말소리 평가 또는 구강개방 이 잘 되지 않는 상태의 말소리 평가, 그리고 말 속도에 따른 차 이를 평가하는 데 적용되어왔다(Dagenais et al., 2006; Han, 2010; Law et al., 2009; Song, 2011).

한편 의사소통 과정은 정보의 정확한 전달뿐 아니라 화자에 대한 이미지 평가에도 중요한 요인으로 여겨지고 있다. 말소리 는 의사소통 수단 중에서도 매우 큰 비중을 차지하며 화자의 이미지에 큰 영향을 미친다. 발음의 정확성을 넘어서서 음성 그 자체만으로도 듣는 이로 하여금 "재미있다", “편안하다", "똑똑 하다"와 같은 긍정적인 이미지를 주거나 또는 그 반대로 "지루하 다" "불안하다", "우둔하다"와 같은 부정적인 이미지를 줄 수 있 다(Choi, 2008). 더 나아가 정상 음성이 아닌 거친 음성의 발화에 서도 이와 유사한 이미지 차이를 초래하기도 하며, 강의 음성으 로서의 느낌이나, 말 명료도, 높낮이, 말속도, 강도 등에서 부정 적인 인식을 나타낼 수 있다는 점을 보여준 연구도 있다(Song, 2015). Lee \& Cheong(2013)은 한국 대학생들을 대상으로 영어 화자 발화 내용의 논리적인 전문성과 발음의 유창성에 차이가 있는 조작된 발화 샘플을 사용하여 이들의 평가를 분석하여 보았다. 이 연구에서의 영어 화자 발화 유창성은 반복, 연장, 막 힘과 같은 말더듬 증상이 없는 상태를 뜻하는 것이 아니라 원 어민의 발화에 가깝게 느껴지는 발음과 연음 특성을 말한다. 그 결과 영어 발음의 유창성으로 화자에 대한 인상이 달라질 수 있음을 확인할 수 있었다. 또한 Kwon \& An(2014)은 말더듬 성인의 비유창성 정도에 따른 일반 청자의 인식을 조사하여 보 았는데 그 결과, 일반인들은 정상 화자에 비하여 말더듬 성인 의 말을 들었을 경우 성격의 특성, 발화의 자연스러운 정도, 편 안함의 정도, 고용 호감도에서 유의한 차이를 보이며 부정적인 인식을 하는 경향을 나타내었다. 해외의 연구에서도 초등학생 을 대상으로 치경마찰음 $/ \mathrm{s} /$ 를 치간음화시키는 오류 발화를 들 려주고 평가하게 해보았는데, 그 결과, 비록 그 오류는 말 명료 도를 심각하게 손상시키지는 않았지만 또래 집단으로부터 부 정적인 시선을 받게 하는 것으로 나타났다(Hall, 1991). 
이러한 연구 결과들은 치경마찰음 /ㅅ, 씨를 치간음화시키는 성인들 역시 그 발음의 특성 때문에 자음정확도, 말 명료도, 말 용인도에, 또는 더 나아가 화자의 이미지에 부정적인 영향을 받 을 수 있음을 말해준다. 이는 이미지 메이킹이 매우 중요한 현대 사회에서 발음의 문제가 화자에게 매우 불리하게 작용할 수 있 음을 예측하게 한다.

이에 연구자는 정상 성인의 발화에서도 비교적 자주 접하게 되는 치간음화된 /ㅅ, 씨 / 음소의 단어나 문장을 듣고 훈련받은 언어치료사가 아닌, 일반 성인들이 정상 조음에 비하여 어떻게 지각하는지 알아보고자 하였다. 이를 위하여 치조마찰음 /ㅅ, 씨의 정상 산출이 가능한 성인 여성의 단어와 문장, 그리고 이 말소리들을 치간음화시키는 성인 여성의 단어와 문장의 낭독 자료를 녹음하여 일반 여대생들을 대상으로 말 명료도와 말 용인도를 평정하게 하고 비교하여 보기로 하였다. 이를 위한 연 구 문제는 다음과 같다.

첫째, 정상 /ㅅ, 씨 단어와 치간음화된 /ㅅ, 씨 단어의 말 명 료도에 차이가 있는가?

둘째, 정상 /ㅅ, 씨 단어와 치간음화된 /ㅅ, 씨 단어의 말 용 인도에 차이가 있는가?

셋째, 치간음화된 /ㅅ, 씨 단어의 말 명료도와 말 용인도에 차이가 있는가?

넷째, 정상 /ㅅ, 씨 문장과 치간음화된 /ㅅ, 씨 문장의 말 명 료도에 차이가 있는가?

다섯째, 정상 /ㅅ, 씨 문장과 치간음화된 /ㅅ, 씨 문장의 말 용인도에 차이가 있는가?

여섯째, 치간음화된 /ㅅ, 씨 / 문장의 말 명료도와 말 용인도에 차이가 있는가?

\section{MATERIALS AND METHODS}

\section{연구 대상}

\section{말 자료 수집 대상}

말 명료도와 말 용인도 평정의 자료로 사용될 말 자료의 수 집은 정상 /ㅅ, 씨 말소리 산출이 가능한 성인 여성과, /ㅅ, 씨 말소리를 치간음화시켜 발음하는 성인 여성 각 1명씩을 대상으 로 하였다. 정상 /ㅅ, 씨 산출 대상자와 치간음화된 /스, 씨 산 출 대상자 모두 부산에서 출생한 부산 거주자이며, 만 20세 6 개월과 만 21세로 연령이 유사한 성인 여성이었다. 임상 경력 10 년 이상인 언어치료사에게 이 대상자들에게 실시한 '우리말 조음음운평가(Urimal Test of Articulation and Phonology, UTAP)' 영상을 보여주고 자음정확도와 모음정확도를 체크하게 한 결과 정상 /스, 씨 산출 대상자는 자음과 모음 모두 $100 \%$ 의
정확도를 보였으며, 치간음화된 /ㅅ, 씨 산출 대상자는 /ㅅ, 씨 와 어중초성 /리를 제외한 자음과 모음에서 모두 정조음하는 것으로 평가되었다. 또한 치간음화된 /ㅅ, 씨 / 산출 대상자의 치 경마찰음과 어중초성 /리를 다양한 모음과 결합시켜 심화 검사 를 실시한 결과, 치경마찰음/ㅅ, 씨는 'l” 모음과 결합된 경우에 만 정조음이 가능하였고 그 외의 모음과의 결합에서는 모두 치 간음화시키는 것을 확인할 수 있었다. 어중초성 /리의 경우 정 조음이 산출되는 모음 환경을 찾을 수 없었고, 비일관적으로 생 략하거나 설측음 $/ 1 /$ 로 산출하는 것을 알 수 있었다. 이와 함께 언어치료사에게 '우리말 조음음운평가(U-TAP)’의 문장 발화 자 료를 들려주고 두 대상자의 말 명료도와 말 용인도를 평가하게 한 결과, 정상 /ㅅ, 씨 / 산출이 가능한 성인 여성의 문장 발화에 서 말 명료도와 말 용인도는 모두 $100 \%$ 로 채점되었다. 치간음화 된 /ㅅ, 씨 산출 대상자의 경우 /ㅅ, ㅆ/와 어중초성 /리가 포함 되지 않은 어절만을 모아 채점하게 하였는데, 그 결과 말 명료도 와 말 용인도 모두 $100 \%$ 임을 확인할 수 있었다.

\section{청취자: 말 명료도 및 말 용인도 평정자}

녹음된 / ㅅ, 씨 / 단어와 문장 샘플을 듣고 말 명료도와 말 용 인도를 평정하는 청취자는 평균연령 20세 5개월(standard deviation 1.6)인 건강한 성인 여성 54명이었다. 이들은 청력장애 나 말·언어장애의 경력이 없었고, 평가 당시에 귀 질환을 않고 있지 않았다. 평정자들은 부산 시내 $\mathrm{A}$ 대학교의 언어치료학과 1,2 학년의 저학년 학생으로 '한국어 문법'이나 ‘의사소통장애 개론'은 수강 완료한 상태이지만 정상 말소리나 장애가 있는 말 소리를 듣고 평가하는 훈련이 이루어지는 '음운론’이나 '조음음 운장애' 교과목은 아직 수강하지 않은 상태였다.

\section{연구 자료}

\section{단어검사 자료}

단어 수준의 검사 자료는 2 3음절의 유의미 단어로 어두초 성이나 어중초성에 /ㅅ, 씨가 위치하는 단어 총 36 개였다. 검사 단어는 1) 7개의 한국어 단모음 중에서 'l’를 제외한 'H', ' 1 ', 'ㄱ, 'T', '-,' '才' 6개의 단모음이 들어가는 단어, 2) 하나의 단어에 /시나, /ㅆㄱㄱㅏ 한 번만 들어가는 단어, 3) 치간음화된 /ㅅ, 씨 산출 대상자가 어중초성 /리에서도 오류를 보이기 때문에 어 중초성 /리가 없는 단어, 4) 일상의 사용 빈도를 고려하여 '아 동용 발음평가(Assessment of Phonology and Articulation for Children)'와 '우리말 조음음운평가(U-TAP)'의 검사 단어 리스 트, 또는 Cheon \& Lee(1999)의 /ㅅ, 씨 말소리 평가에 사용되 었던 단어들 중에서 선택하였고, 일부 낱말을 새로 첨가하여 정리하였다. 
1음절 단어는 2 3음절 단어에 비하여 단어 독립적인 말 명 료도 평가 시 난이도가 더 높은 경향이 있으며, 본 연구의 사전 검사에서 실시한 정상 /스, 씨 1 음절 단어 발음의 말 명료도 평 정에서도 비교적 잦은 오류가 나타나 검사 단어에 포함시키지 않기로 하였다. 또한 'l' 모음과 결합된 / 시 씨 단어는 치간음화 시키는 대상자의 /스, 씨 발음에서도 정조음이 가능하였기 때 문에 'I' 모음과 결합된 / 스, 씨 단어는 말 명료도와 말 용인도 평가의 대상으로 하지 않았다. 이와 같은 과정을 거쳐 총 36개 의 평가용 단어를 정리하였다(Appendix).

\section{문장검사 자료}

문장 수준의 검사 자료는 /스, 씨 음소가 어두초성이나 어중 초성에 분포하는 1 3음절 유의미 단어로 구성하였다. 검사 문장 은 1) 36 개의 평가용 단어들 중에서 주로 선택하여 사용하였고, 2) 일부 1 음절 단어를 사용하였으나, 조사와 결합되어 있거나 의미상 주변 어절과 하나의 구를 이루어서 연이어 발음하게 되기 때문에 1음절이 독립적으로 발음되지는 않게 하였으며, 3) 하나의 문장에 3 4번의 /ㅅ, 씨 산출이 들어가고, 4) 평서문으로 발음할 수 있는 문장으로 구성하여 총 10 개로 정리하였다(Appendix).

\section{실험 장비}

총 36 개의 단어와 10 개의 문장은 2 명의 대상자가 각각 R-05 Wave/MP3 Recorder (Roland, Suzhou, China)에 마이크(ECM719, Sony, Japan)를 연결하여 $10 \mathrm{~cm}$ 이상의 거리를 두고 발화하 도록 하여 수집하였다. 녹음된 두 대상자의 단어와 문장 자료는 컴퓨터에 저장하고, 컴퓨터에 탑재되어 있는 Multi-Speech Model 3700 (KayPENTAX, Inc., Lincoln Park, NJ, USA)의 multi dimensional voice program (MDVP)에서 불러와 단어 와 문장을 각각 개별적으로 저장하였다.

\section{연구 절차}

\section{단어와 문장의 수집 및 평정 자료 정리}

평정을 위한 청취 자료는 잡음이 들어가지 않도록 방송실 부 스 안에서 녹음하였다. / 시 씨 발음에서만 차이가 있고 나머지 음도나 강도, 말속도 등에서의 차이를 최소화하기 위하여 주의 하였다. 두 대상자의 발화 모두 일정한 크기로 녹음되도록 디지 털 소음계(Digital Sound Level Meter TES-1350A, TES Electrical Electronic Corp., Taipei, Taiwan)에 $60 \mathrm{~dB}$ SPL 이상의 크기가 나타나는 것을 확인하며 전 과정을 진행하였다. 평가용 낱말과 문장을 인쇄하여 제시한 뒤 보통 말속도의 평이한 높낮 이로 자연스럽게 읽을 수 있도록 2 3회 반복 연습하였다. 단어 와 문장 모두에서 두 대상자의 낭독 속도가 지나치게 빠르거나
느리지 않고 유사할 수 있도록 검사자가 미리 모델링을 하고 낭 독 연습을 하였다. 각 대상자가 녹음한 문장의 평균 음도를 평 가한 결과, 정상 /ㅅ, 씨 산출 대상자의 음도는 $212 \mathrm{~Hz}$, 치간음 화된 /ㅅ, 씨/ 산출 대상자의 음도는 $208 \mathrm{~Hz}$ 로 유사한 것을 확 인하였다. 두 대상자의 녹음된 자료는 청취자의 평정 시간 확보 를 위하여 각 단어와 각 문장 사이의 간격을 10 초로 두었으며, 정상 발음과 치간음화된 발음의 자료가 무작위로 섞이도록 하 였다. 다만 단어와 문장은 따로 분리하여 제시하였고, 단어나 문장 중에서 먼저 제시하는 순서는 약 10 명의 소그룹으로 나눈 평정자 그룹마다 무작위로 정하여 실시하였다.

\section{말 명료도 및 말 용인도 평정검사}

총 54명을 대상으로 실시한 평정 검사는 음향 장치가 구비된 강의실에서 진행되었다. 여러 명을 대상으로 동시에 실시하면 나타날 수 있는 소음, 집중도 등의 문제를 최소화하기 위하여 평정자들을 약 10 명씩의 소그룹으로 나누어서 따로 진행하였 다. 평가 절차 전반에 대한 설명과 말 명료도, 말 용인도에 대한 충분한 설명과 이해 확인을 마친 후, 연습 문제 실습을 포함하 여 단어와 문장 평정에 소요된 시간은 약 25 분 정도였다. 연습 문제 실습은, 연습용 단어와 문장인 /싸움/, /소네 소금 노코 쌈 싸머거/를 이용하여 정상 발음과 치간음화된 발음을 각각 들 려주며 전사하도록 한 뒤 명료도 및 용인도를 체크하게 하였다. 평가하는 소그룹에 따라 정상 발음과 치간음화된 발음을 들려 주는 순서는 무작위로 하되, 진행 과정에서 두 종류 발음의 특 성을 비교하거나 오조음 언급 또는 오조음의 이유에 대한 설명 은 하지 않았으며, 다만 최대한 들리는 대로 받아 적을 것, 그리 고 미리 설명을 들어 이해하고 있는 말 명료도 또는 말 용인도 에 적절한 점수를 체크하도록 하였다. 예를 들어, 치간음화된 /싸움/을 듣고 전사한 후 말 명료도 체크, 정상 문장을 듣고 전 사한 후 말 명료도 체크, 정상 /싸움/을 듣고 전사한 후 말 용인 도 체크, 치간음화된 문장을 듣고 전사한 후 말 용인도 체크와 같은 방식으로 연습하였다. 이때 평정자들이 듣기 적절한 강도 를 찾기 위하여 제시하는 단어와 문장의 음량을 조절하는 과 정을 거쳤으며, 각 소그룹마다 같은 강도로 평가 샘플을 제시 하였다.

실제 평가가 이루어지는 과정도 유사하였다. 각 소그룹마다 정조음과 치간음화된 단어와 문장 전체 자료를 듣고 전사하며 말 명료도를 평정하고, 다시 단어와 문장 전체 자료를 듣고 전 사하며 말 용인도를 평정하였다. 말 명료도와 말 용인도 평가의 순서는 소그룹에 따라 다르게 진행하였다. 단어나 문장을 듣고 말 명료도와 말 용인도를 한 번에 평정하게 하면 나타날 수 있 는 상호작용을 최소화하기 위함이었다.

말 명료도와 말 용인도의 평정은 Song(2011)의 연구에서 사 
용한 방법과 유사하다. 단어나 문장이 제시된 후 평정자들은 우선 들은 단어나 문장을 받아 적었고, 그 후에 말 명료도 또 는 말 용인도를 평정하였다. 말 명료도와 말 용인도 모두 0에서 10 까지의 등간척도로 점수화하였는데, 0 에 가까울수록 '전혀 알아들을 수 없다' 또는 '전혀 자연스럽지 않고 마음에 들지 않 는다를 의미하며, 10 에 가까울수록 '완전히 알아들을 수 있다' 또는 '매우 자연스럽고 마음에 든다를 의미한다고 설명하였다. 전사 및 등간척도를 사용한 말 명료도 및 말 용인도의 평가는 임상과 연구에서 널리 사용되고 있으며, 신뢰할 수 있는 평정 방법으로 인정받고 있다(Law et al., 2009). 또한 평정자 내 신 뢰도 측정을 위하여 대상자의 약 $10 \%$ 에 해당하는 5 명의 학생 을 무작위로 선발하여 다음 날 같은 평정 과정을 실시하였다.

\section{자료 분석}

평정자들의 반응에서 목표 단어와 목표 문장의 정답과 오답 을 찾고, 정답이 아닌 경우는 분석 대상에서 제외하였다(예: /염 소/를 /용호/로, /세타끼/를 /스타키/로 전사한 경우). 다만 치간 음화된 /ㅅ/ 소리를 /ㅆ/로 전사한 경우나, 치간음화된 /씨 소리 를 /E, 따로 전사한 경우는 음향학적으로 다르게 산출되는 소 리를 다르게 듣는 증거이므로 이를 오답으로 간주하지 않았다 (예: /수박/ $\rightarrow$ /쑤박/, /쌍둥이/ $\rightarrow$ /땅둥이/로 전사한 경우). 또 한 치간음화된 음소 자체를 th로 표기해서 전사한 경우도 있었 는데(예: /사자/ $\rightarrow$ /th자지로 전사) 이 역시 오답으로 간주하지 않았다(정조음 발화의 정답률: 단어 $94.28 \%$, 문장 $91.66 \%$, 치 간음화 발화의 정답률: 단어 $86.11 \%$, 문장 $83.33 \%)$. 정답 문항 만을 대상으로 하여 0 10점으로 평정한 말 명료도와 말 용인 도 점수의 평균을 구하였다. 이와 같은 분석 방식은 Park et al. (2010)의 연구에서 사용한 분석 방법의 특성을 반영한 것으로 평정자가 정확히 알아듣지 못한 단어나 문장을 높은 말 명료 도와 말 용인도로 평정한 경우를 분석에서 제외하기 위함이다.

말 명료도와 말 용인도 평정치의 신뢰도 확인을 위하여 5 명 의 학생을 무작위로 선정하여 평정자 간 신뢰도를 구해보았다. $\operatorname{Han}(2010)$ 의 신뢰도 계산 방식과 마찬가지로 0 10점 범위 중 \pm 2점 차이로 평정한 경우는 일치하는 것으로 간주하여 일치 도를 구한 결과, 말 명료도의 단어 평균 $96.75 \%$, 문장 평균 $94.66 \%$, 말 용인도의 단어 평균 $94.88 \%$, 문장 평균 $93.2 \%$ 의 비 교적 높은 일치도를 확인할 수 있었다. 또한 반복 측정을 통한 평정자 내 신뢰도를 측정하기 위하여 같은 방법으로 5 명의 자료 를 반복 측정한 결과, 말 명료도의 단어 평균 $97.14 \%$, 문장 평균 $95.45 \%$, 말 용인도의 단어 평균 $95.84 \%$, 문장 평균 $94.44 \%$ 의 비 교적 높은 일치도를 확인할 수 있었다.

\section{통계 분석}

통계 분석은 SPSS Statistics 23(IBM Corp., Armonk, NY, $\mathrm{USA}$ )을 이용하여 paired $t$-test를 실시하였으며, 통계학적 의 의는 $p$ 값이 0.05 이하인 경우로 정의하였다.

\section{RESULTS}

\section{정상 및 치간음화된 /ㅅ, $\mu$ / 단어의 말 명료도 비교}

정상 산출된 /ㅅ, 씨 단어와 치간음화된 /ㅅ, 씨 단어의 말 명 료도에 차이가 있는지 알아보기 위하여 두 조건의 단어 자료를 청취하고 평정한 말 명료도 점수를 비교하여 보았다. 전체 36 개 의 단어를 대상으로 비교한 결과, 정상 산출된 /ㅅ, 씨 단어의 말 명료도 평정 점수가 치간음화된 /스, 씨 단어의 말 명료도 평정 점수보다 유의미하게 높았음을 알 수 있었다(Table 1).

\section{정상 및 치간음화된 / $ᄉ, \mu /$ 단어의 말 용인도 비교}

정상 산출된 /ㅅ, 씨 단어와 치간음화된 /ㅅ, 씨 단어의 말 용인도에 차이가 있는지 알아보기 위하여 두 조건의 단어 자료 를 청취하고 평정한 말 용인도 점수를 비교하여 보았다. 전체 36 개의 단어를 대상으로 비교한 결과, 정상 산출된 /ㅅ, 씨 단어의 말 용인도 평정 점수가 치간음화된 /ㅅ, 씨 단어의 말 용인도 평 정 점수보다 유의미하게 높았음을 알 수 있었다(Table 2).

\section{치간음화된 /ᄉ,$\mu /$ 단어의 말 명료도 및 말 용인도 비교}

치간음화된 /ㅅ, 씨 단어의 말 명료도와 말 용인도에 차이가 있는지 알아보기 위하여 치간음화된 /ㅅ, 씨 단어 자료를 청취 하고 평정한 말 명료도 점수와 말 용인도 점수를 비교하여 보았 다. 전체 36개의 단어를 대상으로 비교한 결과, 치간음화된 /ㅅ, 씨단어의 말 명료도 평정 점수가 말 용인도 평정 점수보다 유 의미하게 높았음을 알 수 있었다(Table 3).

Table 1. Comparison of word speech intelligibility between two conditions

\begin{tabular}{lcclccc}
\hline & \multicolumn{2}{c}{ Normal } & & \multicolumn{2}{c}{ Interdental } & \multirow{2}{*}{$t$} \\
\cline { 2 - 3 } \cline { 5 - 6 } & Mean & SD & & Mean & SD & \\
\hline /s/ words & 9.83 & 0.26 & & 9.01 & 1.13 & $6.352^{* *}$ \\
/s*/ words & 9.75 & 0.39 & & 8.85 & 1.21 & $6.793^{* *}$ \\
\hline
\end{tabular}

${ }^{* *} p<0.001$. SD: standard deviation

Table 2. Comparison of word speech acceptability between two conditions

\begin{tabular}{lcclccc}
\hline & \multicolumn{2}{c}{ Normal } & & \multicolumn{2}{c}{ Interdental } & \multirow{2}{*}{$t$} \\
\cline { 2 - 3 } & Mean & SD & & Mean & SD & \\
\hline /s/ words & 9.57 & 0.47 & & 7.31 & 1.66 & $11.274^{* *}$ \\
/s*/ words & 9.36 & 0.64 & & 6.72 & 1.91 & $11.290^{* *}$ \\
\hline
\end{tabular}

${ }^{* *} p<0.001$. SD: standard deviation 
Table 3. Comparison of word speech intelligibility and speech acceptability in interdentalized condition

\begin{tabular}{|c|c|c|c|c|c|}
\hline & \multicolumn{2}{|c|}{ Speech intelligibility } & \multicolumn{2}{|c|}{ Speech acceptability } & \multirow{2}{*}{$t$} \\
\hline & Mean & $\mathrm{SD}$ & Mean & $\mathrm{SD}$ & \\
\hline /s/ words & 9.01 & 1.13 & 7.31 & 1.66 & $8.743^{* *}$ \\
\hline$/ \mathrm{s}^{*} /$ words & 8.85 & 1.21 & 6.72 & 1.91 & $8.808^{* *}$ \\
\hline
\end{tabular}

${ }^{* *} p<0.001$. SD: standard deviation

Table 4. Comparison of sentence speech intelligibility between two conditions

\begin{tabular}{lcccccc}
\hline & \multicolumn{2}{c}{ Normal } & & \multicolumn{2}{c}{ Interdental } & \multirow{2}{*}{$t$} \\
\cline { 2 - 3 } & Mean & SD & & Mean & SD & \\
\hline /s, $\mathrm{s}^{*} /$ sentences & 9.73 & 0.57 & & 8.85 & 1.31 & $6.151^{* *}$ \\
\hline${ }^{* *} p<0.001$. SD: standard deviation & & & &
\end{tabular}

\section{정상 및 치간음화된 / $ᄉ, \mu$ / 문장의 말 명료도 비교}

정상 산출된 /ㅅ, 씨 문장과 치간음화된 /ㅅ, 씨 문장의 말 명료도에 차이가 있는지 알아보기 위하여 두 조건의 문장 자료 를 청취하고 평정한 말 명료도 점수를 비교하여 보았다. 전체 10 개의 문장을 대상으로 비교한 결과, 정상 산출된 /ㅅ, 씨 문장 의 말 명료도 평정 점수가 치간음화된 /ㅅ, 씨 문장의 말 명료 도 평정 점수보다 유의미하게 높았음을 알 수 있었다(Table 4).

\section{정상 및 치간음화된 / $ᄉ, \mu /$ 문장의 말 용인도 비교}

정상 산출된 /ㅅ, 씨 문장과 치간음화된 /ㅅ, 씨 문장의 말 용 인도에 차이가 있는지 알아보기 위하여 두 조건의 문장 자료를 청취하고 평정한 말 용인도 점수를 비교하여 보았다. 전체 10개 의 문장을 대상으로 비교한 결과, 정상 산출된 /ㅅ, 씨 문장의 말 용인도 평정 점수가 치간음화된 /스, 씨 문장의 말 용인도 평정 점수보다 유의미하게 높았음을 알 수 있었다(Table 5).

\section{치간음화된 /ㅅ, $\mu$ / 문장의 말 명료도 및 말 용인도 비교}

치간음화된 /ㅅ, 씨 문장의 말 명료도와 말 용인도에 차이가 있는지 알아보기 위하여 치간음화된 /스, 씨 문장 자료를 청취 하고 평정한 말 명료도 점수와 말 용인도 점수를 비교하여 보았 다. 전체 10 개의 문장을 대상으로 비교한 결과, 치간음화된 /스, 씨 문장의 말 명료도 평정 점수가 말 용인도 평정 점수보다 유 의미하게 높았음을 알 수 있었다(Table 6).

\section{DISCUSSIONS}

본 연구는 정상 성인의 발화에서 비교적 자주 접할 수 있는 치간음화된 /ㅅ, 씨 음소의 단어나 문장을 언어치료사가 아닌 일반 성인들이 정상 조음에 비하여 어떻게 지각하는지 알아보 고자 하였다. 이를 위하여 한국어 치경마찰음의 정상 산출이 가능한 성인 여성의 /ㅅ, 씨 단어와 문장, 그리고 이 말소리들
Table 5. Comparison of sentence speech acceptability between two conditions

\begin{tabular}{lccllll}
\hline & \multicolumn{2}{c}{ Normal } & & \multicolumn{2}{c}{ Interdental } & \multirow{2}{*}{$t$} \\
\cline { 2 - 3 } & Mean & SD & & Mean & SD & \\
\hline ls, $\mathrm{s}^{*} /$ sentences & 9.44 & 0.84 & & 6.96 & 1.87 & $11.073^{* *}$ \\
\hline
\end{tabular}

${ }^{* *} p<0.001$. SD: standard deviation

Table 6. Comparison of sentence speech intelligibility and speech acceptability in interdentalized condition

\begin{tabular}{|c|c|c|c|c|c|}
\hline & \multicolumn{2}{|c|}{ Speech intelligibility } & \multicolumn{2}{|c|}{ Speech acceptability } & \multirow{2}{*}{$t$} \\
\hline & Mean & $\mathrm{SD}$ & Mean & $\mathrm{SD}$ & \\
\hline /s, s*/ sentences & 8.85 & 1.31 & 6.96 & 1.87 & $9.170^{* *}$ \\
\hline
\end{tabular}

${ }^{* *} p<0.001$. SD: standard deviation

을 치간음화시키는 성인 여성의 /ㅅ, 씨 단어와 문장 낭독 자료 를 녹음하여 여대생 54명을 대상으로 말 명료도와 말 용인도를 평정하게 하여 비교해 보았다. 그 결과 정상 산출된 /ㅅ, 씨/ 단어 의 말 명료도 및 말 용인도 평정 점수가 치간음화된 / 시, 씨 단어 의 말 명료도 및 말 용인도 평정 점수보다 유의미하게 높았으며, 치간음화된 / 스, 씨 단어의 말 명료도 평정 점수가 말 용인도 평 정 점수보다 유의미하게 높은 것으로 나타났다. 또한 정상 산출 된 /ㅅ, 씨/ 문장의 말 명료도 및 말 용인도 평정 점수 역시 치간 음화된 /ㅅ, 씨 문장의 말 명료도 및 말 용인도 평정 점수보다 유의미하게 높았으며, 치간음화된 /ㅅ, 씨 문장의 말 명료도 평 정 점수가 말 용인도 평정 점수보다 유의미하게 높은 것으로 나 타났다. 이와 같은 결과는 심각한 조음 오류가 아닌 경우에 말 명료도보다 말 용인도 점수가 더 낮게 나타났다는 Ellis(1999)의 연구 결과와 유사한 경향임을 확인할 수 있었으며, 치간음화된 단어나 문장은 알아들을 수 있을지라도 자연스럽게 들리지는 않는다는 의미로 해석할 수 있을 것으로 판단된다.

본 연구의 결과는 치간음화된 /ㅅ, 씨 음소가 청지각적으로 훈련된 언어치료사가 아닌 일반인에서도 명료하거나 자연스럽 게 들리지 않는다는 것을 지적해준다. 이러한 차이를 가져오는 이유에 대하여 선행 연구들을 살펴본 내용은 다음과 같다.

Song(2017)은 말 명료도 및 말 용인도와 같은 청지각적 평가 에서 정상 발화의 경우와 유의미한 차이를 보인 치간음화된 /ㅅ, 씨 음소를 스펙트로그래프로 시각화하여 어떠한 특성을 보이 는지 살펴보았다. ' $F$ ', 'H', 'T' 모음과 각각 결합된 /ㅅ, 씨 음소 단어인 /산, 새, 수박, 쌍둥이, 쎄미나, 국쑤/를 광대역 스펙트로 그래프로 그려서 관찰한 결과, 치간음화된 /ㅅ, 씨의 자음 구간 이 정상 산출된 /ㅅ, 씨의 자음 구간보다 더 긴 경향이 있음을 알 수 있었다. 이는 /ㅅ, 씨를 구개음화, 치간음화, 설측음화로 왜곡시키는 초등학생 조음음운장애 아동의 발화를 음향학적 으로 비교 분석한 Yang(2016)의 연구 결과와도 일치하는 내용이 다. 저자는 이 연구에서 조음음운장애 아동이 치조마찰음 / 스, 씨 조음 시에 센 기류와 강한 에너지, 긴장을 동반하여 성대 
사이로 기류가 빠르게 빠져나오게 함으로써 제대로 된 소음의 생성이 어렵고, 구강 내 혀의 긴장으로 민첩하고 순간적인 마찰 이 어려워 정확한 마찰음 산출이 어렵다는 점을 지적하였다. 그 에 비하여 일반 아동은 /스, 씨 산출 시에 순간적인 마찰 에너 지가 생성되어 마찰 구간에 강한 에너지가 집중되고 그로 인해 음향학적 파라미터인 무게중심 값이 증가하는 것을 확인할 수 있었다고 한다. 이는 Song(2017)의 스펙트로그래프에서도 유사 하게 관찰되는 특징인데, 치간음화된 /ㅅ, 씨/의 스펙트로그래프 에서 자음 구간의 에너지 분포는 영어의 / $/ \mathrm{e} /$ 와 유사하게 정상 발화된 음소에 비하여 상대적으로 에너지가 약한 것을 관찰할 수 있었고, 또한 마찰 소음의 에너지 분포 영역 자체가 더 넓은 주파수 범위로 퍼져있는 것을 알 수 있었다. Ferrand(2006)에 의하면 일반적인 치경마찰음 $/ \mathrm{s}, \mathrm{s}^{*} /$ 는 $4,000 \mathrm{~Hz}$ 이상의 범위에 마찰 소음을 나타내는데, 이 연구에서 분석한 스펙트로그래프 에서 정상 산출된 /ㅅ, 씨는 실제로 $4,000 \mathrm{~Hz}$ 위에 에너지가 분포하였으나, 치간음화된 /ㅅ, 씨는 관찰 영역 0 17,000 Hz 전 영역에 걸쳐 희미하게 에너지가 분포하는 것을 확인할 수 있었 다. 치간음화된 /ㅅ, 씨의 이와 같은 음향학적인 특성으로 인하 여 훈련받지 않은 일반 여대생의 청지각적 평가인 말 명료도와 말 용인도 평정에서 정상 산출 말소리와 달리 인식함으로써 유 의미한 차이가 나타난 것으로 여겨진다.

한편, Park(2013)은 한국인 영어 학습자들을 대상으로 영어 $/ \mathrm{s} /$ 와 $/ \Theta /$ 의 인지 특성을 연구하기 위하여 초성을 $/ \mathrm{s} /$ 로 시작하 는 단어 'sigh'와 'sock', /s/로 끝나는 단어 'peace', 그리고 / / /로 시작하는 단어 'thanks'와 $/ \theta /$ 로 끝나는 단어 'youth'를 원어민 교수의 발음으로 녹음하고, 자음 구간 및 모음 구간을 늘리거나 줄여 실험 자료를 만들어 이 학습자들의 반응을 분석하여 보았 다. 그 결과 'sigh'에서의 /s/는 대부분 / 씨로 인식하였고, 'sock'에 서의 /s/는 약 75\%에서 /ㅅ/로 반응하였다. 또한 'thanks'에서 /e/ 는 거의 대부분의 학생이 /ᄄᄄ 로 인식하였고, 'youth'에서의 /ब/ 는 대부분 / 시나 /히로 인식하는 것으로 파악되었다. 연구자 는 이와 같은 연구 결과가 차용어에서의 초성 / / / 는 마찰 구간 이 매우 짧기 때문에 우리말의 마찰음보다는 /ᄄ/로 인식하는 것 같고, 끝소리에서의 $/ \theta /$ 는 선행하는 모음의 길이나 청자의 개 인적인 차이에 따라 / 시나 /히 같은 마찰음으로 듣는 경향이 있는 것 같다고 설명하였다. 결국 마찰 소음의 지속 시간이 청 지각적 평정자에게 영향을 미치는 요인이 될 수 있음을 이 연구 에서도 확인할 수 있었다.

따라서 일반인의 경우에도 치간음화와 같은 미세한 음향학 적인 차이는 그 자체로 정상 발화와 다르게 청지각적으로 인식 될 수 있으나, 인식되는 발음의 종류는 그 소음의 지속 시간에 따라 달라질 수 있으며, 더 나아가 발성기관 및 조음기관의 다 양한 근긴장이나 민첩성에도 영향을 받아 음향학적인 파라미
터에 복합적으로 영향을 미치고, 그 결과 청자의 인상을 좌우 할 수 있게 된다는 것을 알 수 있었다.

본 연구의 결과 치경마찰음 / ㅅ, 씨를 치간음화시키는 오류 는 평정 점수의 특성상 말 명료도와 말 용인도를 심각하게 손 상시키지는 않지만, 결국 정상 발화보다는 덜 명료하고 덜 자연 스러운 발화로 듣는다는 점을 알 수 있었다. McKinnon et al. (1986)은 대학생들을 대상으로 말더듬, 과다비성, 그리고 설측 음화된 말소리를 정상 말소리와 같이 녹음하여 들려주고 그들 의 반응을 비교하여 보았다. 그 결과, 정상 말소리에 비하여 장 애 말소리에 대해서는 사회적인 거리감, 저평가, 낮은 이해도, 높은 불안감의 경향이 있음을 발견하였다. 즉, 장애 말소리를 산출하는 대상에 대하여 부정적인 인식을 하는 것을 알 수 있 었으며, 연구자들은 언어치료사들이 이러한 경향을 잘 인식하 고 대상자들의 치료에 적용할 뿐 아니라 그들의 권리를 보호할 수 있도록 노력해야 할 것을 주장하였다.

또한 Ha \& Huh(2018)는 말소리에서 음도와 강도, 그리고 속 도를 변화시켜 그에 대한 청자의 인식 변화를 살펴보았다. 그 결과, 한 가지 또는 2 3가지 요소를 변화시켰을 때 말소리에 대 한 인식이 부정적으로 변하는 것을 관찰할 수 있었다. 이와 같 은 연구 결과는 초분절적인 요소의 변화만으로도 부정적인 이 미지가 생길 수 있다는 것을 알게 해주었으며, 더 나아가 분절 요소인 음소의 왜곡 역시 이미지에 부정적인 영향을 미칠 수 있음을 예측하게 한다. 다만 주의할 것은, 언어치료사와 일반인 들의 유창성 인식에 차이가 있는지 설문 조사를 진행하여 구어 요인, 언어 요인, 태도 요인, 기타 요인 각각에서 일반인이 언어 치료사와 유의한 차이를 보이는 항목들이 따로 있다는 점을 제 시한 Shin et al.(2013)의 연구와 같이 언어치료사가 중요하게 생각하는 요인과 일반인이 중요하게 생각하는 요인이 다를 수 있으므로 그에 대한 조사와 연구가 필요하고 그 결과들을 치료 에 적극 반영할 수 있어야겠다는 점이다.

다른 한편 $\operatorname{Shin}(2015)$ 은 일반 성인과 말더듬 성인을 대상으 로 설문 조사를 실시하여 말더듬 성인들이 일반 성인들에 비하 여 유창성 인식 요인들을 더 중요하게 생각하는 경향이 있음을 보여주었다. 즉 말더듬는 대상들은 일반인들보다 의사소통 관 련 요인들에 더 민감하고, 더 신경을 쓰며, 더 잘해야 한다는 스 트레스를 가지고 있다는 결과를 참고하면, 일반 성인들에 비교 적 자주 나타나는 치경마찰음의 치간음화에 본인들이 어떤 인 식을 가지고 있는지 궁금해진다. /ㅅ, 씨 치간음화 오류를 보이 는 일반 성인들이 자신의 말에 대하여 인식하는 특성, 일반인 들이 이에 대해 느끼는 이미지의 차이, 언어치료사가 받아들이 는 문제점의 정도가 서로 다를 수 있기 때문에 이에 대한 추후 연구가 필요할 것이다.

Lee(2013)는 외국어로서 한국어를 학습하는 외국인의 한국 
어 발음을 평가할 때 채점자의 교육 경력이나 전공 영역의 차 이로 채점 경향이 달라지는지 알아보았다. 그 결과 1 년 이상 한 국어 교육 경력이 있는 교사들은 모두 평정자 간 신뢰도가 있었 으나 경력에 따라 채점의 관대함과 엄격함에 있어 차이가 있었 다. 또한 다양한 전공 영역에 따라서도 이들의 발음을 평가하 는 패턴이 다름을 알 수 있었다. 이는 언어치료사의 경우에도 경력이나 선행 전공의 차이에 따라 인식하는 민감도가 다를 수 있음을, 더 나아가 일반인들도 평정자의 개인 특성에 따라 발 음 평가의 채점 경향이 달라질 수 있음을 예상하게 한다. 그러 나 이러한 고려 사항의 가능성에도 불구하고 본 연구의 결과 는, 말소리 평가를 훈련받지 않은 일반인도 음향학적으로 민감 하게 변별해야 하는 치간음화 오류를 비교적 부정적으로 인식 한다는 점을 제시해주었다. 결국 /ㅅ, 씨 / 음소를 치간음화시키 는 성인의 발음은 언어치료사뿐 아니라 일반인의 귀에도 덜 명 료하고 덜 자연스러운 것으로 들린다는 점과 함께 이로 인한 부정적 이미지가 가능할 수 있음을 예측하게 해준다. 향후 일 반 성인에서 흔히 나타나는 치간마찰음의 왜곡 오류에 대한 일 반인들의 이미지에 대한 연구가 필요할 것이다,

본 연구는 동일 대상자가 아닌 서로 다른 성인 여성을 대상 으로 단어와 문장 발화를 수집하여 비교한 한계를 가지고 있 다. 두 대상자의 성별과 연령, 말소리 높이나 말속도 등에서 최 대한 차이를 줄이기 위해 노력을 했지만 그럼에도 불구하고 말 소리의 지각에 영향을 미치는 음색이나, 모음 공간 등 동일 대상 자가 아니기 때문에 가능한 문제들이 있을 수 있다(Choi, 2007). 따라서 추후 연구에서는 마찰음의 치간음화 오류와 정조음이 모두 동일 인물에서 비교 가능한, 예를 들면 치료 전의 치간음 화 발음과 치료 후의 정조음을 비교할 수 있는 연구가 진행되 면 좀 더 신뢰할 수 있는 연구 결과를 얻을 수 있을 것으로 여 겨진다. 또한 언어치료사가 아닌 일반인을 대상으로 한 말 명료 도 연구에서는 동일하게 정조음한 단어의 쌍 또는 오조음한 단 어를 포함한 쌍을 들려주고 "같다-다르다"와 같이 차이점을 변 별하게 하는 방식으로 진행할 수도 있을 것이다. 그리고 치간음 화된 치경마찰음이 결합된 모음에 따라 말 명료도 및 말 용인 도에 차이가 있을 수 있는지 살펴보는 연구도 흥미로울 것으로 여겨진다. 그 밖에도 경상도 거주민의 경우 일부는 /ㅅ/와 /씨 를 구별하여 산출하지 못하는 경우가 있는데 이 사례에 대한 말 명료도나 말 용인도를 살펴보는 것도 의미 있을 것이다.

중심 단어 : 치간음화·말 명료도·말 용인도.

\section{Ethical Statement}

The author explained the purpose and procedure of this study to the participants, and received the consent of each subject who was willing to participate in this study.

\section{Acknowledgments}

N/A

\section{Declaration of Conflicting Interests}

There are no conflict interests.

\section{Funding}

This Research was supported by the Tongmyong University Research Grants 2018 (2018F068).

\section{REFERENCES}

Cheon, H. J. \& Lee, S. H. (1999). The Development of Korean /s/ (/人/) and /s'/ (/从/) in normal children of ages 2-7 Years. Communication Sciences and Disorders, 4(1), 1-24.

Choi, Y. G. (2007). A review on speech perception of Korean. Journal of Rehabilitation Science, 25(2), 89-106.

Choi, Y. G. (2008). A study on the predictions of impression evaluation of speech voice. Journal of Speech and Hearing Disorders, 17(1), 123-145.

Dagenais, P. A., Brown, G. R., \& Moore, R. E. (2006). Speech rate effects upon intelligibility and acceptability of dysarthric speech. Clinical Linguistics and Phonetics, 20(2-3), 141-148.

Ellis, L. W. (1999). Magnitude estimation scaling judgments of speech intelligibility and speech acceptability. Perceptual and Motor Skills, 88(2), 625-630.

Ferrand, C. T. (2006). Speech Science: An Integrated Approach to Theory and Clinical Practice. (2nd ed.). London: Pearson.

Ha, B. M. \& Huh, M. J. (2018). The effect of pitch, duration, and intensity on a preception of speech. Journal of Speech-Language and Hearing Disorders, 27(3), 45-54.

Hall, B. J. C. (1991). Attitudes of fourth and sixth graders toward peers with mild articulation disorders. Language, Speech, and Hearing Services in Schools, 22, 334-340.

Han, J. S. (2010). Comparisons of the percentage of correct consonants, speech intelligibility, and speech acceptability of single-syllable words in children with cleft palate, children with functional articulation disorder, and typically developing children. Communication Sciences and Disorders, 15(3), 397-410.

Heo, H. J. \& Seong, C. J. (2015). Acoustic characteristics of the Korean alveolar fricative /s/ as observed from 3-year-old and 7-year-old children with respect to the vowel environments. Journal of the Linguistic Society of Korea, 72, 85-112.

Kang, J. H. (2016). Relationship between auditory-perceptual rating and acoustic parameters of fricatives. (Unpublished master's thesis). Myongji University, Seoul.

Kwon, D. H. \& An, J. Y. (2014). Listener perceptions according to disfluency level of stutterers. Journal of Speech and Hearing Disorders, 23(4), 1-13.

Law, I. K., Ma, E. P., \& Yiu, E. M. (2009). Speech intelligibility, acceptability, and communication-related quality of life in Chinese alaryngeal speakers. JAMA Otolaryngology-Head and Neck Surgery, 135(7), 704-711.

Lee, H. (2013). Study of raters' rating patterns on a pronunciation criteria in speaking assessment-Focusing on rater experience and major. Korean Language Education as Foreign Language, 39, 213-245.

Lee, M. J. \& Cheong, T. Y. (2013). A study of university student's cognition on English pronunciation (pp.328-328): Proceedings of 2013 Conference on the Korean Psychological Association. Daejeon: Convention Center.

McKinnon, S. L., Hess, C. W., \& Landry, R. G. (1986). Reactions of college students to speech disorders. Journal of Communication Disorders, 19(1), 75-82

Park, J. E., Kim, H. H., Shin, J. C., Choi, H. S., Sim, H. S., \& Park, E. S. (2010) Speech evaluation variables related to speech intelligibility in children with spastic cerebral palsy. Phonetics and Speech Sciences, 2(4), 193-212.

Park, S. N. (2013). A study on the perception of English /s/ and / $\theta /$ by Kore- 
an students. (Unpublished master's thesis). Hanyang University, Seoul.

Pyo, H. Y., Lee, J. H., Choi, S. H., Sim, H. S., \& Choi, H. S. (1999). An acoustic and aerodynamic study of Korean fricatives and affricates. Speech Science, 6(1), 145-161.

Shin, M. S. (2015). Memorable characteristics of the fluency factor of stuttering adults. Journal of Speech and Hearing Disorders, 24(1), 123-133.

Shin, M. S., Joen, H. S., Kim, H. J., \& Jang, H. J. (2013). A comparative study on perception importance of speech pathologists and normal adults into fluency recognition factor. Journal of Speech and Hearing Disorders, 22(1), 223-234.

Shriberg, L. D. \& Kent, R. D. (2013). Clinical Phonetics. (4th ed.). Boston, MA: Pearson Education.

Song, Y. K. (2011). Characteristics of speech intelligibility and speech ac- ceptability connected with mouth opening condition. Phonetics and Speech Sciences, 3(3). 141-148.

Song, Y. K. (2015). Undergraduate students' emotional response and characteristics of receptiveness as a lecture voice to hoarse and normal reading voice. Audiology and Speech Research, 11(4), 320-330.

Song, Y. K. (2017). Spectrograph characteristics of interdental fricative $/ s, s^{\star} /$ in Korean word level: A preliminary study. Proceedings of the 5th $\mathrm{Col}$ laboration on Korean Speech-Language and Hearing Assocication · Korean Academy of Speech-Language Pathology and Audiology. Busan: BEXCO. Yang, M. G. (2016). Acoustic-phonetic characteristics of fricatives distortion in children with normal and functional articulation disorders. (Unpublished master's thesis). Myongji University, Seoul. 
APPENDIX

평가 단어 및 문장 리스트

\begin{tabular}{|c|c|c|}
\hline \multirow[b]{2}{*}{ 단어(36개) } & $\mid s /$ & $/ s^{*} /$ \\
\hline & $\begin{array}{l}\text { /사자/, /생일/, /소금/, /수박/, /스키/, /우산/, /동생/, } \\
\text { /염소/, /고수/, /풍선/, /구슬/, /사이다/, /세타끼/, } \\
\text { /소방차/, /선풍기/, /스위치/, /나카산/, /앵무새/, } \\
\text { /아기소/, /팓뼁수/, /우주선/ }\end{array}$ & $\begin{array}{l}\text { /싼타/, /책쌍/, /학쌩/, /치쏠/, /국쑤/, /눈썹/, /버쓰/, } \\
\text { /쌍둥이/, /쎄미나/, /씀바귀/, /눈싸움/, /코뿔쏘/, } \\
\text { /복쑹아/, /낙써장/, /테니쓰/ }\end{array}$ \\
\hline \multirow[b]{2}{*}{ 문장(10개) } & \multicolumn{2}{|c|}{$/ s, s^{*} /$} \\
\hline & $\begin{array}{l}\text { /소네 소금 노코 쌈 싸머거/ } \\
\text { /쌍둥이 동생이 눈싸움 한다/ } \\
\text { /테니쓰 고수가 버쓰 타고 간다/ } \\
\text { /앵무새가 우산 쓰고 나카산 탄다/ } \\
\text { /학쌩이 쎄미나 가서 복쑹아만 멍는다/ }\end{array}$ & $\begin{array}{l}\text { 서메 인는 수페 새가 산다/ } \\
\text { 싸타가 팓뼁수 멍는 거 봐써/ } \\
\text { 책쌍에 국쑤와 씀바귀가 이꾸나/ } \\
\text { 처풍기에 사이다만 이쓰면 그마니야/ } \\
\text { 대ㄲㅓㅏㅏㅇㅇㅔ 원숭이하고 코뿔쏘만 이꾸나/ }\end{array}$ \\
\hline
\end{tabular}

